\title{
СИСТЕМА КОМПЛАЕНС ЯК ЕЛЕМЕНТ ПОДАТКОВОЇ БЕЗПЕКИ УКРАЇНИ
}

Коломісць П. В.

\section{ВСТУП}

Сучасна сфера справляння податків i зборів, яку регулює Податковий кодекс України (далі - ПКУ), є високоризикованою, що зумовлено наявністю таких податкових ризиків, як корупція, офшор, пільги, недоїмка, тіньова економіка, недосконала податкова термінологія та неякісне податкове законодавство, фіктивні підприємства й ухилення від виконання свого конституційного обов'язку по сплаті податків. Перелічені ризики загрожують податковій безпеці України, адже вони $є$ чинниками ненаповнення державного бюджету. Саме тому у сфері оподаткування необхідно дотримуватися вимог законодавства, яке регулює відносини у сфері справляння податків. Недотримання цієї вимоги може спричинити незворотні наслідки як для самої держави, так і для платників податків. Запобігання цим негативним наслідкам $\epsilon$ завданням ефективної системи податкового комплаєнсу як елементу податкової безпеки України.

Загальновідомо, що комплаєнс є характерним для різних галузей і сфер діяльності в усьому світі, зокрема для медицини, промисловості, сільського господарства і фінансової сфери. Проведене дослідження історії появи поняття «комплаєнс» у фінансовій сфері показує, що воно з'явилося у 2005 р. із виданням у світ Базельським комітетом із банківського нагляду документа під назвою «Compliance and the compliance function in banks» ${ }^{1}$. Цим документом було встановлено 10 принципів комплаєнсу. Цього ж року Bank for International Settlements видає документ під назвою «BIS Compliance Charter», яким описує рамки управління комплаєнс, аби діяльність фінансової установи та її співробітників проводилася відповідно до правил, політики, процедур, організаційних стандартів і кодексів поведінки, прийнятих Банком, і найвищих етичних стандартів². Наступним кроком розвитку комплаєнсу, проте поки в банківській сфері, стало видання тим самим Базельським комітетом із банківського нагляду вже іншого документа

\footnotetext{
1 Compliance and the compliance function in banks: Basel Committee on Banking Supervision. 2005. URL: https://www.bis.org/publ/bcbs113.pdf. (дата звернення: 28.02.2020).

2 BIS Compliance Charter. Bank for International Settlements. Revised on 17 March 2018. URL: https://www.bis.org/about/compliancecharter.pdf. (дата звернення: 28.02.2020).
} 
«Corporate governance principles for banks», де комплаєнс було виокремлено як принцип під номером $9^{3}$.

Постановою Правління Національного банку України від 28 березня 2007 р. № 98 «Про схвалення Методичних рекомендацій щодо вдосконалення корпоративного управління в банках України» в царину фінансової сфери України було введено поняття «комплаєнс», яке у цих рекомендаціях вживалося у такому значенні: «дотримання вимог законодавства та внутрішніх процедур (комплаєнс) - необхідність знати, розуміти та дотримуватися всіх вимог законодавства України, нормативів, положень і правил, внутрішніх політик, стандартів і кодексів із питань діяльності банку» ${ }^{4}$.

\section{1. Погляди науковців на компласнс}

Аналітичний огляд вітчизняних наукових публікацій у сфері досліджень комплаєнсу свідчить про те, що їхня тематика є доволі широкою. Науковці досліджують: комплаєнс-контроль, комплаєнс у бізнесадмініструванні, фінансові комплаєнс-стратегії, антикорупційний комплаєнс, регуляторний комплаєнс, системи комплаєнс, комплаєнс як основи фінансової стабільності та комплаєнс безпеки.

Зокрема, Н.В. Москаленко, досліджуючи теоретичні аспекти запровадження комплаєнс-контролю в Україні, вказує: «Про суттєве значення комплаєнса у сучасному економічному житті свідчить те, що на Всесвітньому економічному форумі у швейцарському Давосі серед чотирьох сфер, покращання яких дозволить прискорити зростання як світової, так і національних економік, експерти назвали скорочення бюрократії, боротьбу з корупцією, спрощений доступ до фінансування та кредитів, а також активне застосування комплаєнс-практики. У вітчизняній економіці склалося чітке розуміння того, що комплаєнс-контроль $є$ важливим елементом системи корпоративного управління, і вигода від його впровадження значно перевищує ризики, які виникають за його відсутності. Сьогодні комплаєнс-контроль у нашій державі має популярність тільки в банківському секторі, але необхідне його запровадження на всіх рівнях національної економіки. Українські компанії поступово осмислюють важливість застосування комплаєнс-контролю, спираючись на

3 Corporate governance principles for banks: Basel Committee on Banking Supervision. 2015. URL: https://www.bis.org/bcbs/publ/d328.pdf. (дата звернення: 28.02.2020).

4 Про схвалення Методичних рекомендацій щодо вдосконалення корпоративного управління в банках України : Постанова Правління Національного банку України від 28 березня 2007 p. № 98. URL: https://zakon.rada.gov.ua/laws/show/v0098500-07/ed20070328. (дата звернення: 28.02.2020). 
досвід зарубіжних країн» ${ }^{5}$ Резюмуючи своє дослідження, Н.В. Москаленко зазначає, що «комплаєнс» - це поняття, поширене переважно у банківській сфері. Під ним розуміють процес управління ризиками, направлений на добросовісне виконання законодавства, норм етики, прийнятих у сфері регулювання правовідносин і принципів ділових відносин із метою підтримки належних правил і стандартів поведінки на ринку, а також підтримання іміджу установи, організації́.

Актуалізуючи проблему комплаєнсу у бізнес-адмініструванні та його ролі у створенні ефективних норм господарської поведінки, О.В. Овсієнко стверджує, що високий ступінь економічної свободи та можливість вільної реалізації соціально-економічних прав кожного суб'єкта суспільства є сучасним орієнтиром розвитку багатьох країн світу. Відносно успішно цей тренд реалізується у країнах, де вдалося створити таку інституціональну систему, норми господарської поведінки якої спрямовують економічних агентів до соціально-орієнтованого порядку на основі принципу верховенства права. На жаль, в Україні така інституціональна система все ще відсутня, наслідками чого $є$ високий рівень корупції, монополізації економіки, численні неправомірні порушення права приватної власності, уможливлені, серед іншого, діями державних агентів, штучно створена асиметрія у реалізації контрактних прав. Тому виникає потреба пошуку таких напрямів інституційного проектування економіки, які б забезпечили стійкий попит із боку суб'єктів господарювання на втілення принципу верховенства права у систему норм, що регламентують їх взаємовідносини. Одним із таких інститутів $є$ комплаєнс, широко розповсюджений у господарській практиці розвинених країн світу. Комплаєнс відіграє важливу роль у створенні ефективних норм господарювання: він започатковує певний стандарт господарської поведінки, в основі якого - повна прозорість діяльності, неприйняття та запобігання будьяким спробам неправомірного використання ресурсів бізнес-організації. Економічна вигідність такого типу поведінки перетворює бізнес-агентів на провайдерів правової економіки - середовища рівних можливостей у реалізації соціально-економічних прав. У зв'язку з цим перспективи подальших досліджень у цій сфері пов'язані з визначенням та аналізом ефективності конкретних складників комплаєнс-практик, визначенням інституціональних умов їх впровадження 7 .

\footnotetext{
5 Москаленко Н.В. Теоретичні аспекти запровадження комплаєнс-контролю в Україні. Економічний вісник. Серія : Фінанси, облік, оподаткування. 2018. Вип. 2. С. 106-112.

6 Там само.

7 Овсієнко О.В. Комплаєнс у бізнес-адмініструванні та його роль у створенні ефективних норм господарської поведінки. Економічний простір. 2018. № 134. С. 173-185.
} 
Питання безпеки у сучасному світі, як стверджує Г.А. Нерсесян у своій науковій праці «Фінансові комплаєнс-стратегії як універсальні моделі для стратегічного менеджменту у інших галузях бізнесу», набуває неабиякої актуальності, зважаючи на постійні зміни та кризові ситуації на міжнародній арені. Саме тому, на думку вченого, сфера комплаєнсу, що визначається як відповідність певним нормам, пришвидшено розвивається. Україна на своєму шляху інтеграції до міжнародного співтовариства також переймає основні трендові напрями у цій сфері. Якщо ж говорити про Україну, вказує автор, то на законодавчому рівні поняття «компла$\epsilon$ сн» не $є$ визначеним офіційно, але відображене у фінансовій документації, зокрема в положеннях Національного банку України. Г.А. Нерсесян зауважує, що саме поняття комплаєнс-стратегій прийшло в Україну не із законодавства у сфері розвитку бізнесу, а разом із міжнародними компаніями, які вийшли на український ринок і за своєю належністю мають відповідати глобальним загальним принципам, що диктуються головними офісами. Орієнтуючись на глобальні корпорації, українські компанії переймають досвід у цій сфері. Зважаючи на вищезазначене, наголошує Г.А. Нерсесян, можна дійти висновку, що комплаєнс по своїй суті - це максимально ефективний інструмент, покликаний вберегти компанію від кризових ситуацій та унеможливити втрати. Тому питання розробки комплаєнс-стратегій для компанії $є$ важливим та актуальним. Якщо за кордоном існують спеціальні агентства, які займаються розробкою комплаєнс-стратегій для кожної окремої компанії, то в Україні нині таких сервісів не існує. Тому кожна компанія у своїй діяльності може орієнтуватися лише на міжнародний досвід. Проаналізувавши теперішню ситуацію у сфері комплаєнсу та комплаєнс-стратегій, Г.А. Нерсесян стверджує, що ця тематика активно досліджується у банківській сфері, але не $\epsilon$ розробленою в інших галузях. Водночас нормативно-правова база не $є$ визначеною та чітко закріпленою навіть для банківської сфери. Отже, аналізуючи сучасний стан ринку з підвищеною конкуренцією, питання комплаєнсу як відповідності нормам законодавства, правилам етики та моралі набуває максимальної актуальності. Підхід до створення і впровадження цієї стратегії має бути відповідальним, осмисленим і виходити $з$ топ-менеджменту компанії. Наявність таких стратегій не тільки систематизує роботу співробітників у сфері відповідності, але і убезпечить компанії від цілої низки ризиків ${ }^{8}$.

\footnotetext{
8 Нерсесян Г.А. Фінансові комплаєнс-стратегії як універсальні моделі для стратегічного менеджменту у інших галузях бізнесу. Міжнародний науковий журнал «Інтернаука». 2017. № 15 (2). C. 16-20.
} 
Антикорупційний комплаєнс у системі стратегічного моніторингу кадрової безпеки підприємства став темою наукового дослідження T.В. Момот, у якому вчена акцентує увагу на тому, що останнім часом значна увага до фінансово-економічної безпеки суб'єктів господарювання зумовлена дією численних загроз різного характеру. Забезпечуючи захист підприємства від зовнішніх викликів і пристосовуючись до інших незалежних умов, важливо контролювати внутрішні загрози, які можуть походити зсередини, від працівників. Тому питання моніторингу кадрової безпеки в системі управління фінансово-економічною безпекою підприємств набувають особливого значення. Більшість науковців під кадровою безпекою розуміють стан захищеності суб'єкта господарювання від кадрових небезпек і загроз або трактують ії як процес запобігання негативним впливам на економічну безпеку підприємства за рахунок усунення ризиків і загроз, пов'язаних із персоналом, його інтелектуальним потенціалом і трудовими відносинами загалом 9 .

Дослідивши морфологічний аналіз сутності поняття «комплаєнс» як основу фінансової стабільності банку, О.М. Колодізєв зазначає: «В умовах динамічного розвитку економіки та високої ймовірності настання кризи перед банками постає завдання щодо необхідності пошуку високоефективних методів управління ризиками. Банківські установи у своїй діяльності постійно наражаються на такі ризики, як операційний, юридичний, інформаційний, ризик відмивання коштів тощо. Також існує необхідність побудови внутрішніх бізнес-процесів відповідно до вітчизняних і міжнародних процедур і правил. Ці та інші питання можуть бути вирішені за допомогою дієвого механізму системи комплаєнсу». Комплаєнс як науково-економічна категорія розглядається автором із позицій процесу управління, відповідності нормам, процесу виявлення проблемних ситуацій, системи заходів, направлених на захист інтересів, комплексу заходів. За результатами проведеного О.М. Колодізєвим морфологічного аналізу 26 трактувань цього поняття було виділено три групи ключових характеристик: роль, підходи та ризики. Роль - це ті функції, які має виконувати комплаєнс в рамках установи. Підходи - це думки, з яких трактуються поняття. Ризики - це види ризиків, на запобігання яким спрямований комплаєнс. Результати узагальнення спеціалізованої літератури показали багатогранність і відсутність єдиного підходу до тлумачення

\footnotetext{
9 Момот Т.В., Мізік Ю.І., Політучій С.Я. Антикорупційний комплаєнс у системі стратегічного моніторингу кадрової безпеки підприємства. Актуальні проблеми економіки. 2016. № 6. C. 167-174.
} 
поняття «комплаєнс». Тому автором було виділено істотні ознаки трактування цієї дефініції: дотримання норм, здійснення внутрішнього контролю, елемент структури управління банком, запобігання невиконанню законодавства, запобігання корупції та відмиванню коштів. Науковцем наведено власне тлумачення поняття комплаєнс, сформоване на результатах узагальнення наявних поглядів і підходів, а отже, вирішується основна проблема відсутності уніфікованого підходу до визначення його сутності. Таким чином, «комплаєнс» - це процес управління комплаєнс-ризиками, що виступає однією з функцій банку і банківської системи загалом і на меті якого є контроль за відповідністю державних і внутрішньобанківських норм і правил міжнародним для захисту фінансової безпеки банку ${ }^{10}$.

\section{2. Впровадження нової стратегії дотримання} платниками податкового законодавства (компласнс)

У новинах, наданих 18 липня 2017 р. на офіційному порталі Державної фіскальної служби України (далі - ДФС), міститься інформаційне повідомлення «У ДФС обговорили можливості надання технічної допомоги з боку ЄС», у якому висвітлено таке: «Технічна допомога ЄС у сфері реформування сектору управління державними фінансами стала основною темою для обговорення під час зустрічі Голови ДФС із представниками Європейської комісії. Під час зустрічі зазначалося, що вже узгоджені напрями подальшої підтримки СС процесу реформування системи управління державними фінансами в Україні та завершено підготовку відповідної програми співпраці СС та України на період 2018-2021 pр. «Враховуючи те, що бюджетний процес і збір податків є ключовими питаннями цієї програми, ми вдячні Свропейській комісії за підтримку наших ініціатив у напрямі реформування Державної фіскальної служби. Також ми зацікавлені у доступі до технічної експертизи та досвіду різних країн-членів $\mathrm{CC}$ і міжнародних фінансових установ, що передбачено умовами програми», - наголосив Голова ДФС. Представники СС поінформували про заплановані компоненти та можливості технічної допомоги з боку СС фіскальній службі. Так, зокрема, надання технічної допомоги планується за трьома напрямами. Перший із них стосується мобілізації доходів і передбачає підтримку впровадження нової стратегії дотримання платниками податкового законодавства (комплаєнс) і приєднання до ініціативи ОЕСР з автоматичного обміну інформацією щодо

\footnotetext{
10 Колодізєв О.М., Коцюба О.В. Морфологічний аналіз сутності поняття «комплаєнс» як основа фінансової стабільності банку. Бізнес Інформ. 2018. № 12. С. 365-373.
} 
іноземних фінансових рахунків, що впроваджується в рамках Глобального форуму ОЕСР з прозорості й обміну інформацією з податкових питань. Другий напрям стосується підтримки системи розвитку управління персоналом та антикорупційної політики. Третій напрям - IT-підтримка обміну інформацією між МФУ, ДФС і Казначейством, а також підтримка розвитку IT-систем, автоматизації функцій у системі управління державними фінансами. За словами представників СС, оскільки Стратегія управління державними фінансами та План дій з ії реалізації вже прийняті, важливо забезпечити існування відповідних структур із нагляду та координації процесу реформування, що у свою чергу сприятиме ефективній і своєчасній реалізації реформ» ${ }^{11}$.

20 березня 2018 р. Прес-служба Державної фіскальної служби України публікує на офіційному порталі ДФС України інформаційне повідомлення «Німецьке товариство міжнародного співробітництва (GIZ) підтримає ДФС у впровадженні реформ», у якому зазначає: «Основні напрями співробітництва та пріоритети на 2018 рік обговорили під час зустрічі Голови ДФС та Керівника Програми секторального Проекту «Належне урядування у сфері державних фінансів», що реалізується Німецьким товариством міжнародного співробітництва (GIZ) Доктора Анке Шольц. За словами Голови ДФС, першочергові й основні кроки, на яких сьогодні мають бути сконцентровані зусилля, - це реалізація стратегічних ініціатив ДФС на наступні 2 роки. Крім того, за попередніми результатами експертної місії, що відбувалася у ДФС протягом лютого 2018 р. та була спрямована на проведення оцінки системи податкового адміністрування за допомогою Діагностичного інструменту TADAT, було визначено конкретні напрями роботи ДФС, що потребують посилення, зокрема це управління ризиками, сприяння добровільному дотриманню вимог законодавства (компласнс), забезпечення достовірності поданої звітності. Саме тому ДФС вбачає пріоритетним завданням на 2018 р. перегляд робочих процесів. Реалізація цього проекту вимагає залучення підтримки зовнішніх експертів для забезпечення комплексного підходу, об'єктивності та прозорості. Голова ДФС також зазначив, що всі заплановані стратегічні зміни мають бути реалізовані без негативного впливу на процеси наповнення державного бюджету. «Необхідно надзвичайно виважено підходити до процесу реформ і знайти баланс між можливістю змінювати на краще роботу служби й абсолютно

11 В ДФС обговорили можливості надання технічної допомоги 3 боку EC. URL: http://sfs.gov.ua/media-tsentr/novini/303683.html. (дата звернення: 27.02.2020). 
повноцінно виконувати основне завдання ДФС - наповнення державного бюджету», - наголосив Голова ДФС. У свою чергу Доктор Анке Шольц підкреслила готовність GIZ до продовження співробітництва з ДФС у процесі реалізації реформ. Зокрема, це стосується питань міжнародного оподаткування, імплементації плану дій із протидії стратегіям і практикам розмивання бази оподаткування та виведення прибутків 3-під оподаткування (BEPS), трансфертного ціноутворення, проведення податкових перевірок. Крім того, представники GIZ запропонували запровадження пілотного проекту в Університеті державної фіскальної служби України із впровадження дуальної системи освіти, який відбуватиметься у тісній співпраці з територіальними підрозділами ДФС. «Університет державної фіскальної служби має достатньо потужну матеріальну базу, викладацько-професорський колектив високого рівня. Багато викладачів - це практики, які багато років віддали податковій і митній справі», - підтримав пропозицію GIZ Голова ДФС. За підсумками зустрічі сторони домовилися найближчим часом на рівні експертів детально опрацювати конкретні заходи подальшої спільної роботи. Загалом, співпраця ДФС із Німецьким товариством міжнародного співробітництва триває вже майже 6 років. За цей період із боку GIZ було зроблено чимало для підтримки реформування Державної фіскальної служби України. Зокрема, на регулярній основні співробітники ДФС отримують консультативну допомогу експертів Федерального Міністерства фінансів Німеччини з питань трансфертного ціноутворення, ризикоорієнтованої перевірки підприємств, боротьби з ПДВ-шахрайствами» ${ }^{12}$.

26 липня 2019 р. Прес-служба Державної фіскальної служби України публікує інформацію «У ДФС розпочато підготовку Комплаєнс стратегії», в якій говориться: «У рамках реалізації Програми СС «Підтримка державного управління фінансами для України - EU4PFM» міжнародні експерти EU4PFM провели у ДФС семінар і робочу сесію на тему: «Стратегія сприяння добровільному дотриманню податкового законодавства (Комплаєнс стратегія)». Податковий компласнс комплекс мотивів і стимулів платників, які спонукають їх дотримуватися вимог податкового законодавства, законодавства зі сплати єдиного внеску на загальнообов'язкове державне соціальне страхування та сплачувати податки, збори, платежі. Участь у заході, окрім представ-

12 Німецьке товариство міжнародного співробітництва (GIZ) підтримає ДФС у впровадженні реформ. URL: http://sfs.gov.ua/media-tsentr/novini/331027.html. (дата звернення: 27.02.2020). 
ників ДФС і ДПС, взяли спеціалісти Міністерства фінансів України, Представництва Європейського Союзу в Україні, Представництва Міжнародного валютного фонду в Україні, Департаменту казначейства США. Учасники обговорювали основні передумови податкового комплаєнсу, мотиви та стимули платників, що формують культуру сплати податків, складові частини Комплаєнс-стратегії, очікувані результати iiі впровадження, знайомилися з кращими практиками у цій сфері, планували подальші дії. Це перший крок на шляху до якісних змін у підходах до податкового адміністрування та сприйнятті податкових органів платниками, що дозволить вивести відносини з платниками на зовсім новий рівень, який грунтується на довірі та партнерстві. Розробка та впровадження Комплаєнс-стратегії надасть можливість мінімізувати ризики недотримання платниками вимог податкового законодавства, допомогти платникам уникнути найбільш поширених помилок у майбутньому, максимально спростити подання звітності та сплату податків, спільно вирішувати проблеми й усувати перешкоди» ${ }^{13}$.

Питання податкового комплаєнсу в контексті оцінювання ризиків бізнесу розглянуто у статті, що розміщена в офіційному виданні Державної фіскальної служби України «Вісник» 27 липня 2019 р. № 27-28, у якому пояснюється, що комплаєнс - це обов'язок забезпечити відповідність законодавства і міжнародних норм шляхом розробки та дотримання певних внутрішніх політик і процедур. Комплаєнс-контроль «народився» в банківській сфері. Процедури комплаєнса доволі швидко перейшли з банківської сфери в інші галузі економіки. Порівняно недавно вони почали застосовуватися і в корпоративному податковому контролі. Так виник податковий комплаєнс. Комплаєнс (англ. «compliance» - відповідність, згода) - обов'язок забезпечити відповідність законодавства і міжнародних норм шляхом розробки та дотримання певних внутрішніх політик і процедур. Одним із основних елементів системи податкового комплаєнса (системи корпоративного податкового контролю) є ідентифікація й оцінка податкових ризиків. Проведення ідентифікації та оцінки ризиків $\epsilon$ необхідною попередньою роботою, яка проводиться перед виконанням основного завдання - мінімізації ризиків. Якщо ж контроль податкових ризиків недостатній, то це може призвести до вкрай негативних наслідків: зниження вартості бізнесу, значної переплати податків, адміністративних і карних переслідувань, навіть банкрутства компанії. Розрізняють зовнішні (пов'язані зі зміною

13 У ДФС розпочато підготовку Комплаєнс стратегії. URL: http://sfs.gov.ua/media-tsentr/ novini/386784.html. (дата звернення: 27.02.2020). 
законодавства) і внутрішні ризики (зумовлені відновленням персоналу, впровадженням або модернізацією інформаційних систем, появою нових технологій, запровадженням нових видів товарів, реорганізацією компанії, розширенням ринків збуту тощо). За твердженням автора статті: «Час оптимізацій/офшорів/ухилень закінчився. I як зазвичай хто перший прийме/впровадить нові тренди/технології/ідеї/досягнення, той отримає величезну конкурентну перевагу» ${ }^{14}$.

\section{3. Проблематика податкового комплаєнсу в контексті забезпечення податкової безпеки}

Проблематика податкового комплаєнсу $є$ відносно новою для вітчизняної фінансової науки та правозастосовної практики, зокрема у сфері забезпечення податкової безпеки. Динамічний розвиток соціально-економічних процесів нашої держави, як ззовні, так і з середини, завжди зумовлював удосконалення, законодавче внесення змін у визначення понять «національна безпека», «національні інтереси», «загрози національній безпеці».

Завданням нашого дослідження є порівняльний аналіз цих понять у нормативно-правових актах Верховної Ради України, зокрема:

1) Постанови Верховної Ради України від 16 січня 1997 p. № 3/97-ВР «Про Концепцію (основи державної політики) національної безпеки України» (далі - Постанова № 3/97-ВР);

2) Закону України від 19 червня 2003 р. № 964-IV «Про основи національної безпеки України» (далі - Закон № 964-IV);

3) Закону України від 21 червня 2018 р. № 2469-VIII «Про національну безпеку України» (далі - Закон № 2469-VIII).

Щодо визначення поняття «національна безпека».

Постановою № 3/97-ВР у 1997 р. було закріплено: «Національна безпека України як стан захищеності життєво важливих інтересів особи, суспільства та держави від внутрішніх і зовнішніх загроз є необхідною умовою збереження та примноження духовних і матеріальних цінностей (І. Загальні положення і принципи).

Законом № 964-IV у 2003 р. було визначено, що «національна безпека - захищеність життєво важливих інтересів людини і громадянина, суспільства і держави, за якої забезпечуються сталий розвиток суспільства, своєчасне виявлення, запобігання та нейтралізація

\footnotetext{
14 What is COMPLIANCE, або Як оцінювати податковий ризик? URL: http://www.visnuk.com.ua/uk/publication/100013546-what-is-compliance-abo-yak-otsinyuvatipodatkoviy-rizik?issue $=5715$. (дата звернення: 27.02.2020).
} 
реальних і потенційних загроз національним інтересам у сферах правоохоронної діяльності, боротьби з корупцією, прикордонної діяльності й оборони, міграційної політики, охорони здоров'я, охорони дитинства, освіти та науки, науково-технічної та інноваційної політики, культурного розвитку населення, забезпечення свободи слова та інформаційної безпеки, кібербезпеки та кіберзахисту, соціальної політики та пенсійного забезпечення, житлово-комунального господарства, ринку фінансових послуг, захисту прав власності, фондових ринків і обігу цінних паперів, податково-бюджетної та митної політики, торгівлі та підприємницької діяльності, ринку банківських послуг, інвестиційної політики, ревізійної діяльності, монетарної та валютної політики, захисту інформації, ліцензування, промисловості та сільського господарства, транспорту та зв'язку, інформаційних технологій, енергетики й енергозбереження, функціонування природних монополій, використання надр, земельних і водних ресурсів, корисних копалин, захисту екології та навколишнього природного середовища та інших сферах державного управління при виникненні негативних тенденцій до створення потенційних або реальних загроз національним інтересам (Ст. 1. Визначення термінів)».

Закон № 2469-VIII у 2018 р. закріпив: «Національна безпека України захищеність державного суверенітету, територіальної цілісності, демократичного конституційного ладу та інших національних інтересів України від реальних і потенційних загроз (Ст. 1. Визначення термінів)».

Щодо терміна «національні інтереси».

Постанова № 3/97-ВР вказує, що «національні інтереси України відображають фундаментальні цінності та прагнення Українського народу, його потреби в гідних умовах життєдіяльності, а також цивілізовані шляхи їх створення і способи задоволення (II. Національні інтереси України)».

Законом № 964-IV закріплено: «Національні інтереси - життєво важливі матеріальні, інтелектуальні та духовні цінності Українського народу як носія суверенітету і єдиного джерела влади в Україні, визначальні потреби суспільства і держави, реалізація яких гарантує державний суверенітет України та її прогресивний розвиток».

У Законі № 2469-VIII вказано: «Національні інтереси України життєво важливі інтереси людини, суспільства і держави, реалізація яких забезпечує державний суверенітет України, її прогресивний демократичний розвиток, а також безпечні умови життєдіяльності і добробут їі громадян». 
Щодо терміна «загрози національній безпеці».

Постановою № 3/97-ВР закріплено: «Основні можливі загрози національній безпеці України в найбільш важливих сферах життєдіяльності: у політичній сфері; в економічній сфері; у соціальній сфері; у воєнній сфері; в екологічній сфері; в науково-технологічній сфері; в інформаційній сфері (III. Загрози національній безпеці України)». Основні можливі загрози національній безпеці України в одній із найбільш важливих сфер життєдіяльності - в економічній: неефективність системи державного регулювання економічних відносин; наявність структурних диспропорцій, монополізму виробників, перешкод становленню ринкових відносин; невирішеність проблеми ресурсної, фінансової та технологічної залежності національної економіки від інших країн; економічна ізоляція України від світової економічної системи; неконтрольований відплив за межі України інтелектуальних, матеріальних і фінансових ресурсів; криміналізація суспільства, діяльність тіньових структур. Державна політика національної безпеки визначалася виходячи з пріоритетності національних інтересів і загроз національній безпеці України та здійснювалася шляхом реалізації відповідних доктрин, стратегій, концепцій і програм у різних сферах національної безпеки відповідно до чинного законодавства. Основними напрямами державної політики національної безпеки України в економічній сфері були: недопущення незаконного використання бюджетних коштів і державних ресурсів, їх перетікання в тіньову економіку; контроль за експортно-імпортною діяльністю, спрямованою на підтримку важливих для України пріоритетів і захист вітчизняного виробника; боротьба із протиправною економічною діяльністю, протидія неконтрольованому відпливу національних матеріальних, фінансових, інтелектуальних, інформаційних та інших ресурсів.

Законом № 964-IV вказується таке: «Загрози національній безпеці наявні та потенційно можливі явища і чинники, що створюють небезпеку життєво важливим національним інтересам України». Зокрема, як зазначалося в нормах ст. 7 цього Закону, основними реальними та потенційними загрозами національній безпеці України, стабільності в суспільстві в економічній сфері є: нестабільність у правовому регулюванні відносин у сфері економіки, в т. ч. фінансової (фіскальної) політики держави, та «тінізація» національної економіки.

Закон № 2469-VIII закріпив, що «загрози національній безпеці України - явища, тенденції та чинники, які унеможливлюють чи ускладнюють або можуть унеможливити чи ускладнити реалізацію 
національних інтересів і збереження національних цінностей України». Загрози національній безпеці України та відповідні пріоритети державної політики у сферах національної безпеки й оборони відповідно до положень п. 5 ст. 3 цього Закону визначаються у Стратегії національної безпеки України, Стратегії воєнної безпеки України, Стратегії кібербезпеки України, інших документах із питань національної безпеки й оборони, які схвалюються Радою національної безпеки й оборони України і затверджуються указами Президента України.

Зокрема, у Стратегії національної безпеки України, затвердженій Указом Президента України від 26 травня 2015 р. № 287/201515, серед актуальних загроз національній безпеці України визначено: «3.3. Корупція та неефективна система державного управління: поширення корупції, іiі укорінення в усіх сферах державного управління; слабкість, дисфункціональність, застаріла модель публічних інститутів, депрофесіоналізація та деградація державної служби; здійснення державними органами діяльності в корпоративних та особистих інтересах, що призводить до порушення прав, свобод і законних інтересів громадян і суб'єктів господарської діяльності. 3.4. Економічна криза, виснаження фінансових ресурсів держави, зниження рівня життя населення: монопольно-олігархічна, низькотехнологічна, ресурсовитратна економічна модель; відсутність чітко визначених стратегічних цілей, пріоритетних напрямів і завдань соціально-економічного, воєнноекономічного та науково-технічного розвитку України, а також ефективних механізмів концентрації ресурсів для досягнення таких цілей; високий рівень «тінізації» та криміналізації національної економіки, кримінально-кланова система розподілу суспільних ресурсів; деформоване державне регулювання і корупційний тиск на бізнес; надмірна залежність національної економіки від зовнішніх ринків; неефективне управління державним боргом; зменшення добробуту домогосподарств і зростання рівня безробіття; активізація міграційних процесів унаслідок бойових дій». Серед основних напрямів державної політики національної безпеки України - забезпечення економічної безпеки. Ключовою умовою нової якості економічного зростання є забезпечення економічної безпеки шляхом: деолігархізації, демонополізації та дерегуляції економіки, захисту економічної конкуренції, спрощення й оптимізації системи оподаткування, формування сприятливого

\footnotetext{
15 Про рішення Ради національної безпеки і оборони України від 6 травня 2015 р. «Про Стратегію національної безпеки України» : Указ Президента України від 26 травня 2015 р. № 287/2015. Офіиійний вісник Украӥни. 2015. № 43. Ст. 1353.
} 
бізнес-клімату й умов для прискореного інноваційного розвитку; ефективного використання бюджетних коштів, міжнародної економічної допомоги та ресурсів міжнародних фінансових організацій, дієвого контролю за станом державного боргу; системної протидії організованій економічній злочинності та «тінізації» економіки на основі формування переваг легальної господарської діяльності та водночас консолідації інституційних спроможностей фінансових, податкових, митних і правоохоронних органів, виявлення активів організованих злочинних угруповань і їх конфіскації.

\section{ВИСНОВКИ}

Податкова політика як один із основних напрямів економічної політики держави, про що йдеться у ст. 10 Господарського кодексу України від 16 січня 2003 р. № 436-IV, спрямована на забезпечення економічно обгрунтованого податкового навантаження на суб'єктів господарювання, стимулювання суспільно необхідної економічної діяльності суб'єктів, а також дотримання принципу соціальної справедливості та конституційних гарантій прав громадян при оподаткуванні їх доходів.

Поява нових правових явищ «податкова безпека» та «податковий комплаєнс» вже потребують свого законодавчого закріплення у рамках корегування сучасного бачення поняття «податкової політики».

Тема податкового комплаєнсу як елементу податкової безпеки України дедалі більше зацікавлює податківців, які не хочуть бути осторонь новомодної тенденції - податкового комплаєнсу як сукупності мотивів і стимулів платників, що спонукають їх дотримуватися вимог податкового законодавства.

Податковий комплаєнс - комплекс мотивів і стимулів платників, які спонукають їх знати, розуміти та дотримуватися вимог податкового законодавства, законодавства зі сплати єдиного внеску на загальнообов'язкове державне соціальне страхування та сплачувати податки, збори, платежі.

Запровадження системи податкового комплаєнсу дасть змогу вивести відносини із платниками на зовсім новий рівень, що грунтується на довірі та партнерстві. Система податкового комплаєнсу дасть змогу мінімізувати ризики недотримання платниками вимог податкового законодавства, допомогти платникам уникнути найбільш поширених помилок у майбутньому, максимально спростити подання звітності та сплату податків, спільно вирішувати проблеми й усувати перешкоди в забезпеченні податкової безпеки. 


\section{АНОТАЦІЯ}

Проблематика податкового комплаєнсу $є$ відносно новою для вітчизняної фінансової науки та правозастосовної практики, зокрема у сфері забезпечення податкової безпеки. Сучасна сфера справляння податків і зборів, яку регулює Податковий кодекс України, є високоризикованою, що зумовлено наявністю таких податкових ризиків, як корупція, офшор, пільги, недоїмка, тіньова економіка, недосконала податкова термінологія та неякісне податкове законодавство, фіктивні підприємства й ухилення від виконання свого конституційного обов'язку по сплаті податків. Перелічені ризики загрожують податковій безпеці України, адже вони є чинниками ненаповнення державного бюджету. Саме тому у сфері оподаткування необхідно дотримуватися вимог законодавства, що регулює відносини у сфері справляння податків. Недотримання цієї вимоги може спричинити незворотні наслідки як для самої держави, так і для платників податків. Запобігання цим негативним наслідкам $є$ завданням ефективної системи податкового комплаєнсу як елементу податкової безпеки України. Це питання дедалі більше зацікавлює податківців, які не хочуть бути осторонь новомодної тенденції - податкового комплаєнсу як сукупності мотивів і стимулів платників, що спонукають їх дотримуватися вимог податкового законодавства.

\section{ЛITЕРАТУРА}

1. Compliance and the compliance function in banks: Basel Committee on Banking Supervision. 2005. URL: https://www.bis.org/publ/bcbs113.pdf (дата звернення: 28.02.2020).

2. BIS Compliance Charter. Bank for International Settlements. Revised on 17 March 2018. URL: https://www.bis.org/about/compliancecharter.pdf. (дата звернення: 28.02.2020).

3. Corporate governance principles for banks: Basel Committee on Banking Supervision. 2015. URL: https://www.bis.org/bcbs/publ/d328.pdf. (дата звернення: 28.02.2020).

4. Про схвалення Методичних рекомендацій щодо вдосконалення корпоративного управління в банках України: Постанова Правління Національного банку України від 28 березня 2007 p. № 98. URL: https://zakon.rada.gov.ua/laws/show/v0098500-07/ed20070328. (дата звернення: 28.02.2020).

5. Москаленко Н.В. Теоретичні аспекти запровадження комплаєнсконтролю в Україні. Економічний вісник. Серія: Фінанси, облік, оподаткування. 2018. Вип. 2. С. 106-112. 
6. Овсієнко О.В. Комплаєнс у бізнес-адмініструванні та його роль у створенні ефективних норм господарської поведінки. Економічний простір. 2018. № 134. С. 173-185.

7. Нерсесян Г.А. Фінансові комплаєнс-стратегії як універсальні моделі для стратегічного менеджменту у інших галузях бізнесу. Міжнародний науковий журнал «Інтернаука». 2017. № 15 (2). С. 16-20.

8. Момот Т.В., Мізік Ю.І., Політучій С.Я. Антикорупційний комплаєнс у системі стратегічного моніторингу кадрової безпеки підприємства. Актуальні проблеми економіки. 2016. № 6. С. 167-174.

9. Колодізєв О.М., Коцюба О.В. Морфологічний аналіз сутності поняття «комплаєнс» як основа фінансової стабільності банку. Бізнес Інформ. 2018. № 12. С. 365-373.

10. В ДФС обговорили можливості надання технічної допомоги з боку EC. URL: http://sfs.gov.ua/media-tsentr/novini/303683.html. (дата звернення: 27.02.2020).

11. Німецьке товариство міжнародного співробітництва (GIZ) підтримає ДФС у впровадженні реформ. URL: http://sfs.gov.ua/mediatsentr/novini/331027.html. (дата звернення: 27.02.2020).

12. У ДФС розпочато підготовку Комплаєнс стратегії. URL: http://sfs.gov.ua/media-tsentr/novini/386784.html (дата звернення: 27.02.2020).

13. What is COMPLIANCE, або Як оцінювати податковий ризик? URL: http://www.visnuk.com.ua/uk/publication/100013546-what-is-complianceabo-yak-otsinyuvati-podatkoviy-rizik?issue $=5715$. (дата звернення: 27.02.2020).

14. Про рішення Ради національної безпеки і оборони України від 6 травня 2015 р. «Про Стратегію національної безпеки України» : Указ Президента України від 26 травня 2015 р. № 287/2015. Офіційний вісник України. 2015. № 43. Ст. 1353.

\section{Information about author: Kolomiiets P. V.,} Ph. D., Associate Professor, Associate Professor at the Department of Law Poltava Institute of Economics and Law 6, Monastyrs'ka str., Poltava, Ukraine

DOI https://doi.org/10.30525/978-9934-588-43-3/2.9 